\title{
Posthumanistična kritika \\ kartezijanskega dualizma v liriki Alje Adam in Jane Putrle Srdić
}

\author{
Barbara Jurša Potocco
}

Univerza na Primorskem, Fakulteta za vede o zdravju, Oddelek za kineziologijo, Polje 42, 6310 Izola https://orcid.org/0000-0003-4813-1491

barbara.jursa@upr.si

Izhodišče pričujoče ekokritiške obravnave pesniških zbirk Dolgo smo čakali na dež Alje Adam in To noč bodo hrošči prilezli iz zemlje Jane Putrle Srdić je zavrnitev kartezijanskega dualizma kot za zahodno kulturo značilnega androantropocentričnega modela človeške identitete. Obe deli tematizirata človeško telesnost ter razmerje med človeškim in živalskim skozi prizmo posthumanistične več-kot-človeške identitete, ki se povezuje z neidentitetnim kot tistim, kar se izmakne človeškim konceptom. Obe pesnici spodkopavata hierarhično in kakršnokoli bistveno razlikovanje med človeškimi in ne-človeškimi živalmi, razlike med njunima pristopoma pa ustrezajo dvema smerema, ki ju lahko razločimo znotraj posthumanističnega diskurza: pesniška zbirka Alje Adam ustreza posthumanizmu, ki se osredotoča na zabrisanje ločnice med ljudmi in živalmi, Jana Putrle Srdićpa upesnjuje predvsem kiborški posthumanizem, ki razsvetljenski koncept človeka zamaje tako, da ga zmeša s konceptom stroja. Ekofeministično motivirano prevpraševanje binarne opozicije telo/um pri Adamovi poudarja izkustvo čuječnega naseljevanja lastnega telesa in skozenj umeščenosti v okolje, lirika Jane Putrle Srdićpa s svojimi referencami na posthumanistične ideje Garyja Snyderja in Donne Haraway izpeljuje radikalno posthumanistično preseganje pojmovnih dvojic narava/kultura ter telo/um oziroma zavest/materija predvsem na podlagi ideje o materialni (t.j. tehnološki) biološki) posredovanosti vseh (človeških in nečloveških) zaznav.

Ključne besede: sodobna slovenska poezija / Adam, Alja / Putrle Srdić, Jana / kritika kartezijanskega dualizma / ekofeminizem / posthumanizem / ekokritika 
Ena ključnih skupnih točk pesniških zbirk Dolgo smo čakali na dež (2015) Alje Adam (roj. 1976) in To noč bodo hrošći prilezli iz zemlje (2014) Jane Putrle Srdić (roj. 1975) ${ }^{1}$ je kritika antropocentričnega vrednostnega sistema, utemeljenega posebej v tradiciji kartezijanskega dualizma. René Descartes je v Discours de la mèthode (1637) razum opredelil kot razločevalno človeško lastnost, ki ljudi ločuje od ostalega živega sveta (28-49). Duša, izenačena s čistim razumom, je bila $\mathrm{v}$ tej razpravi razločena od telesa, razum hierarhično postavljen nad telo in afekt ter pripisan samo ljudem, ne-človeške živali pa razglašene za moralno nerelevantne stroje oziroma telesa, ki jih poganjajo zgolj mehanični zakoni. Descartesova moderna paradigma brezdušne narave je sovpadla z mehanicistično metafiziko Isaaca Newtona (Optics, 1704), pa tudi z idejo človeškega gospodovanja nad naravo pri Francisu Baconu (The Great Instauration, 1620), s katero je postala racionalnost do kraja instrumentalizirana (Keller 60). Eksplicitno polemiko z antropocentrizmom v pesništvu Alje Adam in Jane Putrle Srdić je potrebno razumeti natanko v pravkar naznačenem kontekstu, zlasti v okviru opozicije med človeškim in ne-človeškim. Deklarativni primer prevpraševanja kartezijanskega dualizma je pesem Putrle Srdićeve »Temna snov«, spričo povsem eksplicitne reference na Descartesa:

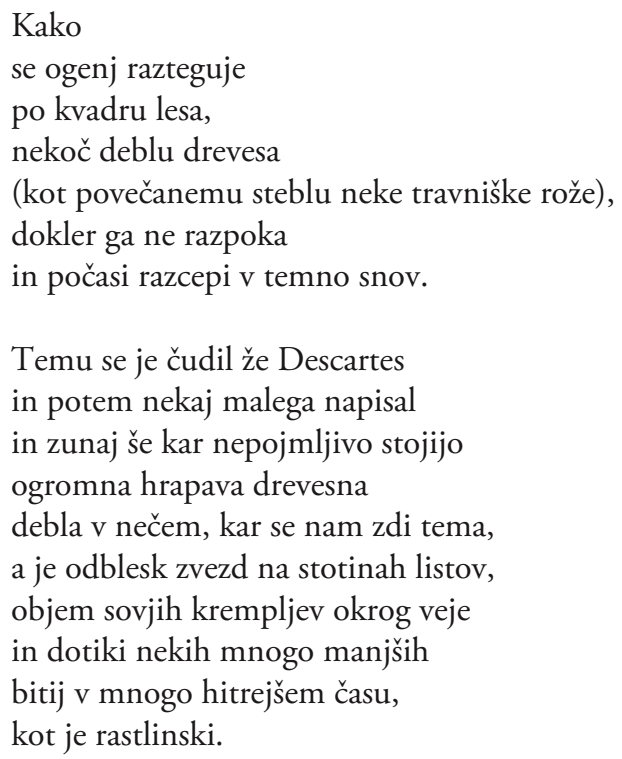

${ }^{1}$ Alja Adam je avtorica pesniških zbirk Zaobljenost (2003), Zakaj bi omenjala Ahila (2009) in Dolgo smo čakali na dež (2015). Jana Putrle Srdić pa je objavila doslej pesniške zbirke Kutine (2003), Lahko se zgodi karkoli (2007), To noč bodo hrošči prilezli iz zemlje (2014) ter Oko očesu vrana (2020). 


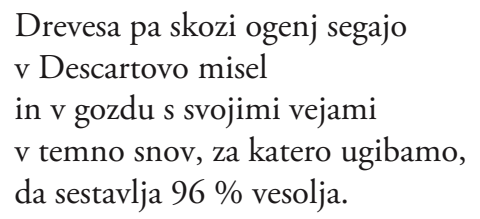

Narava je tema

okrog Descartove misli. (Putrle Srdić, To noč 63)

Preseganje konceptualnega dualizma narava-kultura, ki ustreza simbolizmu teme in svetlobe, temelji zlasti v ekocentričnem širjenju onkraj "naše" perspektive, ki se ji noč zdi temna, v relativizaciji človeške zaznave $s$ perspektivami ne-človeških bitij. Prepletanje motivnih področij človeka, ognja, lesa, noči in debel se pojavlja natanko v funkciji relativizacije kartezijanske razmejitve zavesti od okolja in njenega nadomeščanja z mrežami različnih perspektiv, kar je še posebej razvidno v eksplicitnem razstavljanju dualnosti v podobi, kjer drevesa - kot v kartezijanski misli pasivna "res extensa" - "skozi ogenj segajo v Descartesovo misel« (63).

V zbirki To noč bodo hrošči prilezli iz zemlje je pogosto prisotno preseganje antropocentričnega modela s predstavljanjem svetov, ki obstajajo na različnih mikro in makro ravneh, nevidnih golemu človeškemu očesu. Motivi pesmi, ki pripadajo različnim referenčnim sistemom (nanodelci, nebesna telesa, mišice, žilice, nevroni), odstirajo biološko posredovanost izkustva ter reflektirajo tehnološko posredovanost zaznave, ${ }^{2}$ prav tako pa postavljajo v ospredje koncept mreže kot enega temeljnih modelov sodobne ekološke misli. Zato je za ekokritiško branje zbirke ključnega pomena poglavje, ki je pomenljivo naslovljeno »Mreža» in se pričenja z naslovno pesmijo zbirke, v kateri je izpostavljena vzporednica med "micelijsko mrežo in "povezavami med nevroni« (Putrle Srdić, To noč 61). Metafora mreže je učinkovita postmoderna alternativa binarizmom, ker postavlja v ospredje interakcije in medsebojne odvisnosti, ki ne potekajo med hierarhično ločenimi ravnmi, ampak horizontalno (Claviez 78). Tudi v zbirki Putrle Srdićeve lahko ekocentrični koncept »mreže« kot pluralističnega in rela-

${ }^{2}$ Pesniška zbirka To noč bodo hrošči prilezli iz zemlje se sistematično loteva izpeljave posthumanističnih tem $\mathrm{v}$ korespondenci s sodobnimi umetnostmi, ki so vpete $\mathrm{v}$ refleksijo sodobnih znanosti in tehnologij ter skupaj z njimi prevprašujejo razsvetljenski koncept človeškega. Ta cilj dosledno zasleduje tudi z vizualnim sporočilom na naslovnici, ki prikazuje celično sliko, pri tem pa meša asociacije na vesolje in prst ter tako ilustrira tezo o povezanosti makro in mikro resničnosti v mrežo, aludira pa tudi na koncept »temne snovi«: na eno izmed okroglih, kraterskih celičnih struktur je dorisan tuleči volk, v črnino med njimi pa so dorisani hrošči iz naslova zbirke. 
cijskega modela resničnosti razumemo v okviru neidentitetne ekologije Timothyja Mortona, ki dekonstruira naravo kot sestavljeno iz teles, od katerih je vsako že samo palimpsest simbiotičnih organizmov. Koncept "mreže« (mesh) Morton razume kot alternativo "naravi«, "svetu« in "(eko)sistemu«, ki naj bi predstavljali model sveta kot človeštvu razpoložljivega vira. Mreža je brezsrediščno in neskončno materialno polje medsebojne odvisnosti, ki povezuje žive (človeške in ne-človeške) organizme ter abioto kot "objekte" (Morton, »Coexistence« 175). Ker predpostavlja popolno singularnost vsake življenjske oblike in odsotnost vsakršne fiksne identitete, Morton teoretizira vse življenjske oblike kot "nenavadne neznance« (strange strangers). Ekološko politiko in poetiko utemeljuje na ne-jazu, tj. razumevanju, da smo tudi sami sebi drugi (»nenavadni neznanci«), mišljenju obstoja kot soobstoja in na kolektivnih oblikah identitete, ki vključujejo tudi ne-človeške vrste in njihove svetove (Morton, »The Mesh« 29). Mortonov koncept mreže zajema tudi dekonstrukcijo kraja kot radikalno nedoločenega in potencialno neskončnega (Morton, Ecology 173-74). Skozi večno intimno materialno povezanost stvari so drugi kraji (in časi) del vsakokratnega »tukaj in zdaj" (Morton, The Ecological 55).

Skladno z Mortonovo vizijo mreže lahko v pesniški zbirki To noč bodo hrošč prilezli na zemljo Putrle Srdićeve opazujemo razkrajanje koncepta kraja, ki ga nadomeščajo podobe globalne povezanosti: "potrebno se je postaviti na glavo, sprehoditi se po ulicah Kampale, / Nagpurja, Kuala Lumpurja, kjer iz gnezd padajo papige« (20); "Zadnji zadetki to uro plešejo po nočnih klubih. / Nekdo v beli srajci z zavihanimi rokavi / se v sončnem večeru Curacaa na ulici Kaya Wana / obrne, / kot bi zaslišal zvok iz prihodnosti« (29); "nepremično slediva / vrtenju Zemlje« (89); "Govorili [bomo] o sočasnosti pojavov na Zemlji, / o hkratni iznajdbi ognja na različnih koncih sveta" (91); "Takrat sem prebila realnost na drugi / strani Zemlje in prijela za roko / umirajočo žensko« (67).

V pesniški zbirki Dolgo smo čakali na dež Alje Adam se kartezijanski racionalizem, ki temelji na neupoštevanju (so)odnosnosti med bitji, pojavlja kot določilo, ki vzdržuje strah pred drugim:

\footnotetext{
[...] A korenine pogosto zamenjujemo $\mathrm{z}$ debli, listjem in vejami, zato smo telo iztrgali iz zemlje, postalo je breztežno kot molekule zraka, kot kemijske enačbe, ki smo se jih v šoli učili na pamet.
} 
Ker nas niso peljali v gozd

in nam niso pokazali,

kako položiti dlan vetru na hrbet,

kako uloviti zvoke narave,

se prižeti $\mathrm{k}$ lubju dreves.

Pravijo, da moramo

vso razsežnost svojega bivanja

posrkati v možgane, v dolge verige tkiv,

nabrekle celice zgodovinskega spomina,

v katerih se razmnožuje strah.

Mislim, torej sem? (Adam, Dolgo 81-82)

Kot alternativa kartezijanski hierarhiji in želji po gospodovanju nad svetom in z njim povezanim izkustvom strahu se v zbirki ponavlja telesna receptivnost (poleg citirane pesmi glej npr. Adam, Dolgo 29-30, 53). Telesni dotik/občutje je predstavljeno celo kot trenutek epifanije, ki nasproti dualizmu postavi telo kot entiteto med drugimi telesi, kjer opazovalec ni izvzet iz opazovanega, s čimer z nekoliko drugačnega vidika naslavlja temo, ki jo eksplicitno izpostavlja tudi Putrle Srdićeva v pesmi »Raziskovalci se čudijo» (Putrle Srdić, To noč 23):

[...] Ustavi me brazgotina, padec $\mathrm{z}$ drevesa $\mathrm{v}$ mladosti, trenutek, ko mu ni uspelo odmeriti razdalje med roko in vejo, h kateri se je stegoval, ločiti misli od telesa,

ko je omotičen ležal na tleh in čutil, kako koža drgeta

v sunkih vetra, kako postaja del gibajoče se pokrajine, in celo najmanjši premik oblakov nad njim spremeni celotno podobo neba. (Adam, Dolgo 63-64)

Še jasneje kot Adamova izkustvo strahu in (ne)varnosti v povezavi z dihotomijo narava-kultura postavlja Putrle Srdićeva: »in kadar kdo umre, / se pepel varno zapre v škatlo" (Putrle Srdić, To noč 40); "[p]oskušaš si zamisliti, da je bil to filmski prizor, / kjer med snemanjem ni bila poškodovana / nobena žival (38); "[v]si otroci na kolesih so dobili čelade in okrog tračnic / so izkopali jarke, da ne moremo do njih« (19, glej tudi 72). 
Ob tematizaciji obsedenosti sodobne družbe z zagotavljanjem varnosti pred več-kot-človeškim drugim pri obeh pesnicah se zdi uporabna Adornova in Horkheimerjeva kritika instrumentalnega razuma kot glavnega problema razsvetljenskega projekta emancipacije človeštva. Njuna Dialektika razsvetljenstva (Dialektik der Aufklärung, 1947) postulira medsebojno povezanost dominacije nad naravo, družbene dominacije in dominacije znotraj subjekta, ob razumevanju, da sta narava in družba dialektična celota. Razsvetljenstvo vzpostavlja lažno alternativo med človeškim nadzorovanjem narave in gospostvom narave nad človeštvom, ter postane lastno nasprotje, ko skuša svoj cilj, odpravo človeškega strahu pred naravo, doseči z nadzorom nad "drugim". S povečanjem človeške prevlade nad naravo se nismo izognili neobvladljivim okoljskim tveganjem, ravno nasprotno, prav tako smo tudi sebe podvrgli njenim negativnim posledicam (Görg 46-50). Adorno narave ne želi povsem izenačiti z ne-identiteto, vendar pa obstaja med naravo in ne-identitetnim, ki se izmika človeški misli ali dejanju in je hkrati značilno za vse naše misli in dejanja, velika sorodnost (Gunster 208).

Vse navedeno skoraj samoumevno vodi k branju zbirk v okviru temeljnih, med seboj povezanih konceptov ekokritiške literarne vede, predvsem zato, ker je tudi pri Putrle Srdićevi ob motive dominacije nad naravo, denimo v pesmi "Zračna kletka" (»čelade«, "program: aktivnosti v naravi«, "pristrižena trava«, glej Putrle Srdić, To noč 19), umeščena refleksija, ki usmerja pozornost na telesno navzočnost v sedanjem trenutku (»misli [...] hrepenijo po žeblju, ki bi jih zabil // v ta trenutek«, glej Putrle Srdić, To noč 19), ta pa sega v osvobajajoče polje t. i. divjega oziroma ne-identitetnega. Za obe zbirki je torej smiselno ob že omenjenem konceptu mreže upoštevati posthumanistično idejo več-kot-človeškega, kot se povezuje s konceptom ne-identitetnega, in v luči teh dveh pojmov obravnavati dve bistveni značilnosti obeh zbirk, in sicer izpostavljeni topos telesa ter tematizacijo razmerja med človeškim in živalskim.

\section{Posthumanistična več-kot-človeška identiteta}

Tako v zvezi s pesniškimi besedili Alje Adam kot tistimi Jane Putrle Srdić lahko govorimo o perspektivizmu, relacionizmu in pluralizmu, ki so nezdružljivi s totalizirajočim in esencialističnim pojmom "narave« (Curry 52-53). Širši domet literariziranih idej obeh del nam je dosto- 
nasledka antihumanizma, ki se je pričel uveljavljati s strukturalizmom in poststrukturalizmom. Posthumanizem postulira globoko relacijsko naravo resničnosti, odpravlja novoveški konstrukt človeškega subjekta z vso njegovo ideološko težo, poleg humanističnega "človeka" pa prevprašuje tudi vse na njem utemeljene hierarhične pojmovne pare. $S$ predpostavko, da nečloveško naseljuje samo jedro človeškega, posthumanistična teorija spodreže liberalno tradicijo širjenja sfere političnih svoboščin na marginalizirane družbene skupine, ki še vedno privzema za središče osrednjo definicijo človeka kot moškega, belega itd. (Wolfe 568). Izpostaviti je treba, da fluidno in kontingentno posthumanistično več-kot-človeško sebstvo odpravlja iluzijo človeške ločenosti od drugih življenjskih oblik, z vsemi etičnimi implikacijami, ki jih to prinaša. Specifično posthumanistični uvid $\mathrm{v}$ več-kot-človeško vsepovezanost pojavov živega in neživega sveta izhaja $\mathrm{v}$ veliki meri iz sodobnih znanstvenih spoznanj o izjemni vlogi mikrobiomov za delovanje človeškega organizma ter vključevanju tujih, denimo bakterijskih, genomov v genski zapis človeške vrste (Sagan in Margulis 205). Že preprosti uvid, da je človeško telo sestavljeno iz mnoštva mikroorganizmov, prevprašuje običajno razumevanje več-kot-človeškega "okolja" kot nečesa, kar se nahaja zgolj zunaj naših teles. $S$ posthumanističnega vidika je vsako človeško bitje tako ugledano kot več-kot-človeška skupnost.

Zlasti zbirka To noč bodo hrošči prilezli iz zemlje z ubesedovanjem polja posthumanističnih hibridov in postajanj ločnico med ljudmi in neljudmi povsem jasno zabrisuje onkraj kategorij živega in neživega, tudi onkraj kategorij živali in stroja. Že v pesmi »Temna snov«, ki smo jo navajali, je svet spravljen pod fizikalni pojem »temne snovi«, ki ga lahko označimo s pojmom ne-identitetnega, kar je v kontekstu ekokritiške paradigme pravzaprav izraz za to, kar smo sicer vajeni misliti kot "naravo«. Tako kot za ekokritiško teorijo, je tudi za Putrle Srdićevo pomembna referenca bitniški pesnik, esejist in okoljski aktivist Gary Snyder (1930). ${ }^{3}$ Snyder humanistični koncept narave dosledno nadomešča s posthumanistično idejo »divjega«, ki ga ne smemo razumeti kot necivilizirani prostor, marveč kot lastnost izmikanja zmožnostim nadziranja in razumskega dojemanja; v tem smislu so divji, med drugim, človeško telo, zavest in jezik (Snyder 181). Njegova esejistika sovpada z njegovo lastno pesniško prakso:

${ }^{3}$ Ameriška literarna veda ga označuje za bitnika oziroma sopotnika bitniškega gibanja (Allen xiii). Da je Snyder pomembna ekokritiška referenca, nakazuje dejstvo, da je bila njegova esejistika vključena v ekokritiški zbornik The Green Studies Reader: From Romanticism to Ecocriticism (glej Coupe). 
Squat in swamp shadows. mosquitoes sting; high light in cedar above.

Crouched in a dry vain frame

- thirst for cold snow

- green slime of bone marrow

Seawater fills each eye.

Quivering in nerve and muscle

Hung in the pelvic cradle

Bones propped against roots

A blind flicker of nerve [...]

The long body of the swamp.

A mud-streaked thigh.

Dying carp biting air

in the damp grass,

River recedes. No matter. [...]

The sun dries me as I dance. (nav. po Allen 312)

Citirano besedilo temelji na poenačenju lirskega govorca, šamana, z močvirnim okoljem; seveda Snyder že z evokacijo šamanskega plesa sega v nedualistično percepcijo predkolonialnih ljudstev. A bolj kot motiv je značilna oblikovanost besedila. V identifikaciji močvirja s telesom (»the long body of the swamp«) je izpostavljeno enačenje šamanovega telesa $s$ pokrajino; kitični prelomi $v$ celotni pesmi ustvarjajo prelome v govorčevi perspektivi, ki oscilira med glediščem šamana in naravnega okolja, $s$ katerim je poenačen. Divje, ki ga reprezentira šaman s svojim jezikom (lirski govorec), zavestjo (šaman/močvirje) in telesom, lahko vzporejamo z ne-identitetnim in več-kot-človeškim, s čimer Snyder ubeseduje kartezijanskemu dualizmu nasprotno pozicijo, kjer je ukinjena delitev na subjekt in objekt. Divje več-kot-človeško je pripoznano od znotraj in nerazdružljivo od človeške zavesti same (»One moves continually with the consciousness / Of that other, totally alien, non-human «; nav. po Allen 312).

V pesniški zbirki Jane Putrle Srdić To noč bodo hrošči prilezli iz zemlje je Snyder omenjen v kar treh različnih besedilih, "Naenkrat v prazni hiši« (14), "Revolucija v kuhinji« (27) in »V parku« (56), a le v zadnji izmed teh lahko v stavku "me s Snyderjem nosi do izvora materije« zaznamo jasno aluzijo na Snyderjevo pojmovanje divjega. Tekste Putrle Srdićeve povezuje s Snyderjem ideja odsotnosti vsakršne osebne subjektivitete, ki je opazna tako v Snyderjevi citirani pesmi kot v njegovi esejistiki. Najbolj pri tem izstopa njena pesem "Mišek z lune«, 
kjer je identiteta upovedovana kot evidentno več-kot-človeška: »tvoja rama s prosojno kožo čez / modre vene postaja vesoljska (10); celo razkraja se: "ni te, / vse to je prevara«, »kot prikazni, / ki jih skoraj ni« (10). Nedualno čutenje sveta, onkraj konceptualnega, ki se sklada z razpršenostjo in nedoločenostjo kraja $\mathrm{v}$ neskončnosti prostora, je skoraj programatsko izpisano $\mathrm{v}$ zaključku te pesmi: »In kje si, razpršeni $t i$, I sublimiran v kapljice oblaka, / desetine kilometrov nad kopnim, nad morjem [...] si dež in Indijanec in ples / tam daleč v Arizoni." (11)

Vendar pa Snyderjeve ideje izhajajo iz njegovega svetovnonazorskega prepričanja, utemeljenega $\mathrm{v}$ budistični religiji, kar pomeni, da identitete ne razume kot prividne ali fikcijske pojavnosti, ki bi se nemara celo multiplicirala v med seboj različnih variantah, pri Putrle Srdićevi pa se izčrpanost in nezadostnost identitet do neke mere sklada z duhovnozgodovinskim konceptom postmoderne: "pretežno brezbrižen, pretežno / izropan svet pokupljene preteklosti, / s katero prekupčujemo. // čista fikcija, rečeš." (Putrle Srdić, To noč 52-53) Putrle Srdićeva koncept ne-identitetnega povezuje s pozitivno idejo tehnološkega razvoja, ki se oblikuje na relaciji znanost-kibernetika-umetnost (glej npr. 33, 85-86), pri čemer je emancipatorni moment umetniške kreacije v oblikovanju prihodnosti povezan prav z odnosom do "neznanega» in "neopredeljenega«: »[Ženska] ob oknu [...] razmišlja, ali naj tvega korak v neznano [...] skuša izluščiti nekaj še neopredeljenega." (33) Povezava s kibernetiko kaže, da so pri Putrle Srdić vir za literariziranje razsrediščene in določno več-kot-človeške identitete sodobne meddisciplinarne znanstveno-umetniške prakse, ki premišljujejo odnos med človeškim in ne-človeškim, ter posthumanistične ideje Donne Haraway, feministične teoretičarke, ki je ustoličila subverzivni lik kiborga. Kiborštvo lahko razumemo kot procesualno kolektivno sebstvo, ki spodkopava zahodne dihotomije narava/kultura, organizem/stroj, žival/človek, telo/um, ženska/moški ter nenazadnje fizično/nefizično (Haraway 246-280). Da lahko pesniško prakso Putrle Srdićeve povezujemo z delom te teoretičarke, nakazuje tudi dejstvo, da najdemo v njeni poznejši zbirki (Oko očesu vrana, 2020) posvetilo Harawayjevi, in sicer ob pesmi "Ženske v integriranih vezjih» (Putrle Srdić, Oko 37). A tudi v tu obravnavanih besedilih je nespregledljivo prepričanje $\mathrm{v}$ transformativni potencial sodobnih tehnologij in hibridne subjektivitete. Pesem »Krasni novi svet (trailer)« je možno brati kot tezo za preskok kulture onkraj dualističnega razumevanja tehnologije, ki naj bi razkrivala pravo "vezje« sveta: tehnologiziranost, posredovanost in prividnost "mnoštva vsega«, to je, vseh resničnosti in izkustev: 


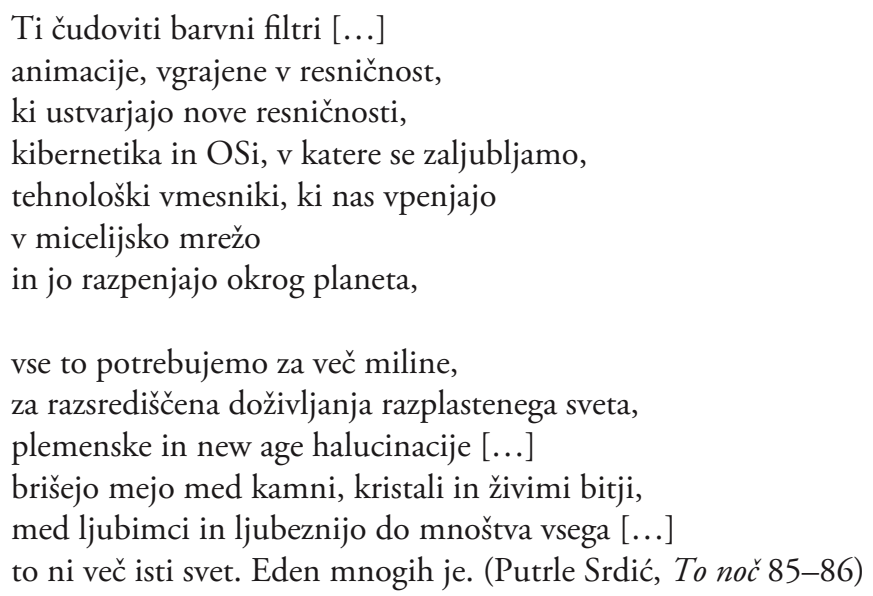

Prelom s paradigmo strogega ločevanja med poljema naravnega in kulturnega/tehnološkega je $\mathrm{v}$ zbirki To noč bodo hrošči prilezli iz zemlje podprt $\mathrm{z}$ interakcijo obeh pomenskih polj v podobju, zlasti v primerih, kjer kot vehikel nastopa leksem iz pomenskega polja tehnologije ali kibernetike - tako se mrak nalaga »kot v računalniški igrici« (7), "spolirani elektromagnetni impulzi« so identifikacija za zvok (79), trenutek je »visokoresolucijsko jasen« (82). Prepletanje obeh polj je še zlasti vidno v pesmi s programskim naslovom "Narava in kultura", ki v koncept narave vključi promet in tehnologijo: »Kako nekontrolirana je narava / v prometnih konicah, nepredvidljivostih / interneta in jutranji toči.» (65) Eden ključnih konceptualnih premikov se $\mathrm{v}$ »Naravi in kulturi« zgodi, ko se romantična podoba narave - gre za opis morske obale - razkrije kot zgolj tehnološko in kulturno posredovana: „tudi to sliko sem nekoč / zgolj videla na ekranu.« (65) Tudi sicer postaja v zbirki motiv prometa simbol skrivnostne avtomatiziranosti, več-kot-človeške urejenosti sveta, ki je navzoča tudi v kaosu in naključju (glej 10, 28). Živa več-kot-človeška materialnost povezuje žive organizme in abioto ("naravo") s tehnologijo (»kulturo») v tolikšni meri, da nima več pravega smisla razlikovati med kulturnimi in ne-človeškimi pojavi. "DNK" kot ena ključnih besednih zvez zbirke vzpostavlja osrednjo temo naravnih zakonov, ki pa se veže tudi na človeško tehnologijo, kar je z ekokritiškega vidika bistveno. DNK je označen kot »samo bolj posrečena / oblika kot 010110100 «(61). Isti več-kot-človeški procesi, ki smo jih navajeni kategorizirati kot »naravne«, se fraktalno ali rizomsko razraščajo in odvijajo tudi skoz to, kar običajno dojemamo kot od narave ločeno "tehnologijo", pri čemer se izmikajo zmožnostim razumskega dojemanja in ostajajo skrivnostni. Naslovna pesem »To noč bodo 
hrošči prilezli iz zemlje«, ki preplete podobe micelijske mreže, gozda, nevronske mreže in DNK-ja, tehnologijo eksplicitno napolnjuje z atributi človeškega: »če si prav redko dovolimo ljubeč / odnos do tehnologije, je zdaj tudi / ona del signala [...] obraz ji žari, kot je dano le redkim, / zelo starim, zelo mladim" (61-62); obenem je tik ob opis tehnologije postavljen na videz naravni prizor: „Nocoj bodo hrošči, ki so se 17 let pod / zemljo hranili s sokovi dreves, hkrati prilezli / na plan in se preobrazili v nekaj drugega." (61-62). Tehnološki procesi in procesi, ki jih navadno razumemo kot naravne, od človeka neodvisne, osvetljujejo drug drugega; tako se iz podobe hroščev izlušči logika, da je tudi premik hroščev programiran.

\section{Topos telesa}

Telo kot del več-kot-človeškega obstoja je v ospredju tako pri Alji Adam kot pri Jani Putrle Srdić. V pesmi »Telo in jezik« Putrle Srdićeva artikulira ekokritiško razumevanje človeškega jezika, saj ne spregleda njegove več-kot-človeške materialne razsežnosti. Jezik je prepoznan kot nanašajoč se na telesno pogojenost naših zaznav: »Telo je prva in zadnja / resnica, ki oklepa besede." (Putrle Srdić, To noč 57) Telo, ki je v celoti vpisano v okolje, je izvor in temelj, referenčna točka vsake besede, saj se jezik porojeva v materialnem kontekstu okolja. Obenem je človekovo telo preko nevronov vpeto $\mathrm{v}$ okoliški tako naravni kot kibernetski svet (61-62), iz česar je šele možna konvergenca med sanjsko, naravno in virtualno sliko pojava v že omenjeni pesmi »Narava in kultura" (65; prim. Potocco). Tudi tematizacija odnosa telo-okolje je podprta z interakcijo pomenskih polj v uporabljenem podobju, pri čemer so leksemi iz semantičnega polja divje narave preneseni ali uporabljeni alternirajoče za naravo in človeka, npr. »ljubim se s tabo kot žareča krogla«, "govoriš z mano kot pragozd «, "[poslovnež ima] popolno funkcionalno predatorsko telo«, itn. (glej Potocco). Toda v zbirki To noč bodo hrošc $c i$ prilezli iz zemlje je primarna točka razpiranja več-kot-človeški identiteti odnos med naravo in tehnologijo. Za posthumanistično kritiko kartezijanskega dualizma pri Adamovi pa je ključna ekofeministično izpeljana tema telesa, odprtega materiji:

Neverjetno srečo imam, da premorem dve roki, dve nogi

in na sredini prsnega koša rdečo, utripajočo mišico [...]

da lahko na koži občutim toploto perja,

v katerega je raca zarila svoj kljun. (Adam, Dolgo 61) 
Po mnenju Wendy Wheeler nam lahko osredotočanje na lastno telo povsem izkustveno predoči našo neposredno udeleženost $\mathrm{v}$ mreži več-kot-človeškega soobstoja in odpravi iluzijo odvezanega človeškega opazovalstva, prav tako pa nam lahko razkrije, da je človeško zdravje odvisno od zdravja več-kot-človeškega sveta, saj se v človeško telo ekološka razmerja vpisujejo ali na način zdravja ali bolezni (Wheeler 12). Če po navadi predpostavljamo, da je narava nekaj, kar je človeku zunanje, in ne proces, ki poteka skozi človeško telo, je z ekofeministične perspektive, kakršno privzema tudi govorka $\mathrm{v}$ poeziji Adamove, telo presečišče vrste odprtih več-kot-človeških sistemov. Njeno perspektivo lahko vzporejamo $\mathrm{z}$ novimi materializmi oz. materialnim feminizmom, za katerega se uporablja tudi oznaka ekoontološki feminizem (glej Bauman). Za razumevanje poskusa vzpostavitve ekofeministične politike telesa-v-okolju, kakršnega opažamo v zbirki Alje Adam, so pomembni prav novi materializmi, ki izhajajo iz feminističnih študijev znanosti in predstavljajo poskus nedualistične redefinicije materije in telesa (Iovino in Oppermann 76). Materijo opisujejo kot artikulirano, komunikativno, intencionalno in kompleksno, pod vplivom konceptov nelokalne korelacije, pretoka energije in informacij ter integriranih sistemov iz kvantne fizike in biologije (76). Za tovrstno revidiranje koncepta materije je ključen pojem materialno-diskurzivnih praks, tj. mišljenje diskurzivnega in materialnega kot ne povsem ločenih kategorij, in razumevanje jezika kot nečesa, kar zadeva telo ter celoto materialnega sveta in ne le privilegirane sfere človeške kulture (Branch 50). Nove materializme včasih označujemo kot panpsihizem ali novi animizem, saj preseganje konceptualne ločnice med fizično materijo in zavestjo kot nečim prvenstveno človeškim uresničujejo kot vračanje $\mathrm{k}$ starim animističnim prepričanjem na načine, ki ustrezajo idejam iz dinamičnega polja sodobnih znanosti. Teoretiki novih materializmov skušajo ponazoriti živo relacijskost materije, ki povezuje ljudi in neljudi, oz. stalno materializacijo pojavov s pomočjo najrazličnejših skovank (Barad, Meeting 392-393). Karen Barad je s svojo teorijo delovalniškega realizma uvedla koncept materialnodiskurzivnih »intra-akcij« (intra-actions), ki za razliko od »interakcij»ne predpostavljajo neodvisno obstoječih delovalnikov (Barad, "Nature's" 32); Shannon Sullivan pa govori o »transakcijah" (transactions), ki potekajo med telesom in okoljem (Sullivan 1) in se v tem konceptu v marsičem približa ideji »čeztelesnosti« (trans-corporeality), kakršno zagovarja Stacy Alaimo (Alaimo 2).

Za podrobnejši vpogled $\mathrm{v}$ širšo povezavo med tematiko telesa in materije $s$ feminističnim političnim projektom pa velja najprej ome- 
niti osrednjo predpostavko ekofeminizma, namreč to, da je razumevanje povezav med modernim uničevanjem več-kot-človeškega okolja in družbenim zatiranjem žensk pomembno tako za feministično kot za ekološko gibanje (Warren 281). Androcentrizem in antropocentrizem sledita isti logiki dominacije, za katero sta značilna dualizem in hierarhija, a povezava gre dlje: androantropocentrični konstrukti identitete človeško telo feminizirajo in animalizirajo hkrati ter mu nadevajo manjvrednostni predznak. Tako ekološki kot feministični politični projekt zajemata skupno predelavo razumevanja našega razmerja z lastno telesnostjo. Odtujitev od lastnega telesa predstavlja posebno obliko ponotranjenega nadzorovanja družbeno markiranih teles, zaradi česar lahko sprejemajoče povezovanje z lastno telesnostjo deluje kot vir osebne moči in način ponovnega "prilaščanja" svojega koloniziranega telesa (Legler 78-79). Dekonstrukcija ideje fiksnega in vase zaprtega človeškega telesa, za kakršno si prizadeva ekološko gibanje, je nekaj, kar za svoj uspeh potrebuje emancipacija vseh marginaliziranih družbenih skupin, saj se njihovo družbeno podrejanje vedno znova sklicuje na fizično, domnevno fiksno razliko med njimi in privilegirano skupino najbolj "človeških « ljudi kot na nekaj vnaprej determiniranega ter določujočega. Opustitev trdne identitetne politike spolnih in drugih opozicij omogočajo šele novi materializmi, ki nam pomagajo dojemati raznolikost, prilagodljivost in ustvarjalnost telesa in materije (Hird 88). Iz tega sledi, da moramo telo, namesto da bi ga odmislili, razumeti kot preveč partikularno, da bi ga lahko zajeli v koncepte, na katerih bi lahko gradili opresivno politiko. Predvsem pa človeškega telesa ne smemo misliti kot trdno določenega in zaključenega produkta, kot $\mathrm{v}$ primeru kartezijanskega automatona, saj ga druga telesa nenehno gradijo in razstavljajo (Gatens 110). Pri ekocentričnih revizijah konceptov telesa in materije je torej treba paziti, da se izognemo vsakršni sledi metafizičnega dualizma (Hayles 49).

Spričo vsega povedanega ne preseneča, da smo v začetku razprave lahko tudi pri Adamovi opozorili na programatično dekonstrukcijo kartezijanskega dualizma (prim. znova Adam, Dolgo 81-82). Na njegovo mesto stopa slavljanje dotika, ki se odreka kulturnoantropocentrični utilitarnosti, oz. »rekonstrukcija bolj telesnega občutka sebstva«, na katero opozarja Böhme (glej Rigby 142-143); naj zadostuje nekaj parafraz zgolj iz pesmi, ki smo jih doslej citirali: "zato smo telo iztrgali iz zemlje«, " [ker] nam niso pokazali, kako položiti dlan vetru na hrbet" (Adam, Dolgo 81-82); »da lahko na koži občutim toploto perja« (61); "ko je omotičen [...] čutil, kako koža drgeta v sunkih vetra" (63-64). Po Böhmeju naj bi v kontekstu tehnološke civilizacije rekonstrukcija 
telesnega občutka sebstva imela status etičnega imperativa; izkušanje telesa je treba zavestno kultivirati tako, da od trenutka do trenutka ostajamo pozorni na telesna občutenja, ki nas postavljajo $\mathrm{v}$ (so)prisotnost drugih ljudi, živali, rastlin, stvari in krajev (glej Rigby 142-43). Prav umetnost pa naj bi bila po mnenju Böhmeja tista, ki uči, kako biti telo, in navaja na ekološke načine bivanja.

Pesniška zbirka Dolgo smo čakali na dež izpostavlja ozaveščanje lastne utelešenosti $v$ popolni skladnosti z Böhmejevim programom in ni naključje, da tudi v drugih pesniških zbirkah Alje Adam pogosto naletimo na motiv gole kože, ki je $\mathrm{v}$ užitku in tudi ranljivosti hvaležno, zaščitniško, vzneseno in vzburjeno izpostavljena stiku z več-kot-človeškim okoljem. Govorkin klic k usmerjanju pozornosti na tukajšnje in zdajšnje je treba razumeti torej tudi $\mathrm{v}$ povezavi z lepoto več-kot-človeškega stika, ki se ga zavedamo kot telo: „Zjutraj sem pozorna na malenkosti, / na poteg stegna ob rjuho, cvrčanje olja, / na vonj, ki me popelje v kuhinjo" (Adam, Dolgo 85); »da bi z mirno roko / v sunkih burje [...] pričvrstila zanko na kavelj / in svojo pozornost / na trenutek" (75). Motiv kože oziroma sprejemanja vtisov skozi odprte pore je posebej izpostavljen v številnih pesmih (prim. 37, 13, 33, 61, 69): »Vsak delček kože, ki ga prepustim dotiku, žari kot zvezde, ki jih [...] opazujem [...,] ko so v vesolju že ugasnile« (93); "Najraje bi začela pri toploti, / ki prehaja skozi pore, v Şkrjančevih pesmih, v avtobusu, / ko sedim tesno ob neznanem sopotniku“ (31). Upesnjevana razpoloženja in ideje vznikajo iz okolja, skozi ozaveščene čutne zaznave, skladno s strategijo kontekstualiziranega diskurza, ki "vpisuje živčni sistem v pokrajino« ter tako povezuje naše telo z našo vednostjo (Cheney 130). Sinestezija, ki je - kot je razvidno tudi iz že citiranih primerov - pogost postopek v pesništvu Alje Adam, se pojavlja kot način upovedovanja mreže povezav med človeškim in ne-človeškim.

Občutenje telesa, kot ga zasledimo v njenih besedilih - zlasti, a ne izključno v zbirki Dolgo smo čakali na dež́ -, bi najlažje opisali kot panerotično: telesni stik z okoljem je opisovan kot erotični čutni užitek, pa naj bo to okolje sonce, veter, dež ali prst, kot denimo v pesmih "Jesen", "Amputacija« in "Pesem, ki diha«, kjer lirska govorka izreka željo po tem, »da bi se dotikala rastlin« in »z rokami gnetla pokrajino: / zdrsnila vanjo

${ }^{4} \mathrm{~V}$ predhodni pesniški zbirki Zakaj bi omenjala Abila je možno to posebej jasno ugledati v pesmih "Drstenje» (denimo "mlado listje zapeljivo žgečka po trebuhih", 52); "Lomilec stolov" (»osvobojeno" telo "zdrsne iz svojih oblačil [...] ter s stegni objame modro nebo«, 48), »Ponovitev« (»dež širi polten vonj mokrih rastlin«, "ekstatično brizganje listja«, 44), "Zakaj bi omenjala Ahila» (dež z nežnimi dotiki »razpre» "pokrajino«, 26). 
kot s prsti v testo" (Adam, Dolgo 83). Govorkin panerotični odnos s svetom nakazuje živost stvari ter je zastavljen kot drža odprtosti in občutljivosti, s kakršno ljudje stopamo v najbolj intimne telesne stike s človeškimi ljubimci. Panerotično podobje torej podpira panpsihistično pojmovanje zavesti kot vseprisotne, navzoče tudi v ne-človeških bitjih in stvareh. Kot panerotični motiv par excellence se v pesmi »Kroženje» pojavi dež, kar glede na naslov zbirke ni presenetljivo. Kroženje iz naslova pesmi se ne nanaša le na krožne gibe samozadovoljevanja, marveč vsaj še na kroženje vode z neba na zemljo in nazaj, s podobo mokre kože pa pride do enačenja užitka ob spolnem dejanju in ob stiku z ne-človeškim, čeztelesnim:

Dež se spušča in dviguje kot žametna zavesa, razkriva svet naših projekcij, mokra koža vztrepeta od nežnosti pod oknom kavarne, kjer se zaljubljenca dotikata,

/.../

nato se ona iznenada zdrzne

in trdno oklene torbice $\mathrm{v}$ rokah,

da bi ohranila ravnovesje med stvarmi,

kot takrat, ko spravlja ponošene obleke v škatle,

ločuje tisto, kar je bilo, od tistega, kar prihaja,

kakor da se čas giblje samo v eno smer,

in bi morali vedno, ko pada dež,

odpreti dežnike, da bi odbili od sebe poželenje,

$s$ katerim odklepam vrata stanovanja,

slačim najlon nogavice,

zdrsnem s prsti

med sramne dlake

in krožim. (Adam, Dolgo 57-58)

\section{Človek-žival}

Četudi ubesedovanje več-kot-človeškega v pesništvu obeh obravnavanih avtoric dobiva različne, bolj ali manj radikalne izraze, je eden od osrednjih načinov transgresije človeškega $\mathrm{v}$ več-kot-človeško problematizacija odnosa med človeškim in živalskim. V obeh izpostavljenih zbirkah je med območji človeškega in živalskega zaznavno "mreženje«, denimo v pesmi "Lepota" Putrle Srdićeve, v kateri naštevani prizori lepega prepletajo tako področja živalskega (gibanje gazele in njenega plenilca, žerjav, žaba) kot kategorije kulturnih produktov (avtomobilski design, sodobna umetnost, tango) (Putrle Srdić, To noč 43). V panpsihistični pesmi "Grlica" Alje Adam oko, ki se s svetlobo v sebi zazira v svet, 
predstavlja inteligentno zavest, ne glede na to, ali je človeško, ribje, pasje ali ptičje, ideja povezanosti z več-kot človeškim živalskim pa zapisana dobesedno:

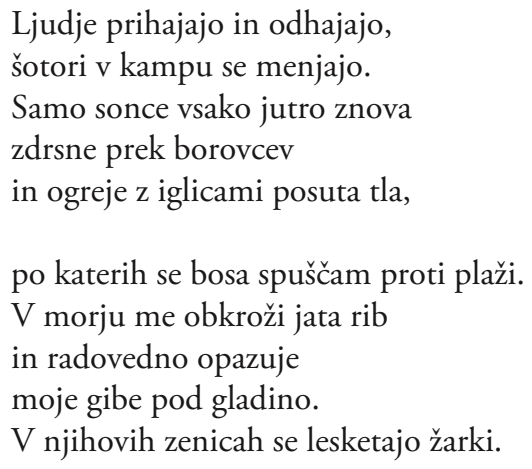

Takrat začutim, da sem povezana z vsem:

ker sem prav tako lesketanje

uzrla v pogledu stare, umirajoče sosedove psičke,

in $\mathrm{v}$ očeh grlice,

ki je pojedla drobtine pod našo mizo,

razprla rep v belo pahljačo

in odletela v nebo. (Adam, Dolgo 73)

Putrle Srdićeva tudi v prepletanju človeškega in živalskega območja uporablja strategijo, ki smo jo omenjali ob širjenju v območje več-kot-človeškega na eni strani v področja narave, na drugi strani v področja tehnologije. Prav ob definiciji lepote naletimo na sledečo podobo: »delfinovi triki so priučena lepota, / podobna gibki erotiki barskih plesalk« (Putrle Srdić, To noč 43). Na ravni metaforike, z alterniranjem človeških, živalskih in tudi drugih več-kot-človeških tenorjev in vehiklov, Putrle Srdićeva zabrisuje mejo med človeškim in ne-človeškim, pa naj bo ne-človeško koncipirano kot nežive reči ali kot ne-človeške živali. Poglejmo samo nekaj primerov: "Ptiči se sprožajo z zvokom budilke» (54); "Srna dirja / pred psom v podivjanih / togih skokih kot začaran / koncertni klavir« (54); »V sobah so ljudje [v] svojih prašičje rožnatih telesih « (54); " [m] orda so lesni črvi socialne živali« (67); "napol odrasli ptiči že letajo / in bo kmalu čas za selitev, / oblačenje, pakiranje, veter pod krili, / kmalu se bomo zaprli, zakurili, zapeli zadrge« (12). Brisanje kategorije človeškega se torej v pesniški zbirki dogaja na način mehčanja meja med človeško in drugimi živalskimi vrstami, a tudi z eksplicitno obrnjenimi vlogami: 
[v] Herzogovem dokumentarcu o Antarktiki,

ki se ne sprašuje o zapletenem vedenju pingvinov,

ampak, zakaj smo tam mi.

Kam kopljemo. (23)

Izpostavljeno je razmerje človek-pes-volk, ki pri Putrle Srdićevi poudarja ambivalentnost prepletanja človeškega in več-kot-človeškega. Postopek, kjer je človek preko psa kot udomačene živali metaforično zbližan z divjo naravo volka, je najbolj eksplicitno izpeljan $\mathrm{v}$ pesmi "Odsotnost «: preplet človeškega in volčjega se izkaže kot možen ne skozi direktno fizično srečanje ("po sedemindvajsetih dneh ena sled «, 70), marveč samo z dvojno posredovanostjo: najprej kulturno posredovanostjo („čakaš pred rdečo in strmiš v plakat $\mathrm{z}$ volčjo glavo ob terenskem vozilu, / bolj resničen od sence, ki jo zasleduješ«, 70); nato s posredovanostjo udomačenega psa (»[s]voje živali s sledjo volka v krvi«, 70). Ne-človeško se izmika človeški želji po prisvajanju skozi konceptualno vednost, namesto tega se na koncu - po metaforičnem posredništvu psa - dogodi uvolčenje človeka, ki razpusti človeško identiteto: »Potem se zviješ na zemljo / in prespiš dnevno svetlobo / v grmovju.« (70)

Interpretacijo, da je več-kot-človeško prisotno v človeku samem, $s$ svojim antitetičnim naslovom (»Bližina«) potrjuje "Odsotnosti« predhajajoča pesem: vez med človekom in volkom je locirana $\mathrm{v}$ genskem zapisu, "mutacij[i] v metabolizmu, / ki pred 32000 leti postane / človekova vez z volkom« (Putrle Srdić, To noč 67-68). V obeh pesmih je več-kot-človeško predstavljeno kot območje hkratne bližine oziroma soobstoja ter odsotnosti. Medsebojna bližina med posameznimi entitetami, ne le med volkom in človekom, marveč tudi med človekom in lesnim črvom, gozdom, debli, knjižnico in knjigami (67-68), je izkušana na način slutnje nelokalne povezanosti, ki se sklada z Mortonovim konceptom več-kot-človeških "nenavadnih neznancev«, naseljujočih isto eko-ontološko mrežo.

Pozicija govorke do razmerja med človeškim in živalskim torej ni nedvoumna, ker hkrati implicira tujost in so-čutenje. Slednje je v pesmih Putrle Srdićeve implicirano posredno: zasledimo, denimo, kritiko pejorativne rabe besede "nečloveški«, ki človeško vrsto hierarhično postavlja nad vse druge: "nečloveška vztrajnost [... C Človeško je ozka kategorija, zverinska / krutost spada vanjo." (Putrle Srdić, To noč 71) Zavrnjeno je antropomorfiziranje živali, ki mu je nasproti postavljena kompleksnost več-kot-človeškega sveta, v kateri ni možno iskati človeških pomenov: »lisica žre mrhovino [...] čebele pijejo roso s cvetnih listov / in muhe znoj s konjskih stegen [...] le brezdelna vztrajnost išče / pomene v oblikah oblakov." (71). V pesmi "(So)čutnost" Alje 
Adam se naslov besedila ne nanaša le na sposobnost empatije. Ob medvrstnih interakcijah ni bistveno le prepoznavanje potreb ne-človeškega drugega, marveč je kot točka konvergence definirana telesna senzibilnost, ista sposobnost čutenja, ki si jo ljudje delimo z drugimi vrstami:

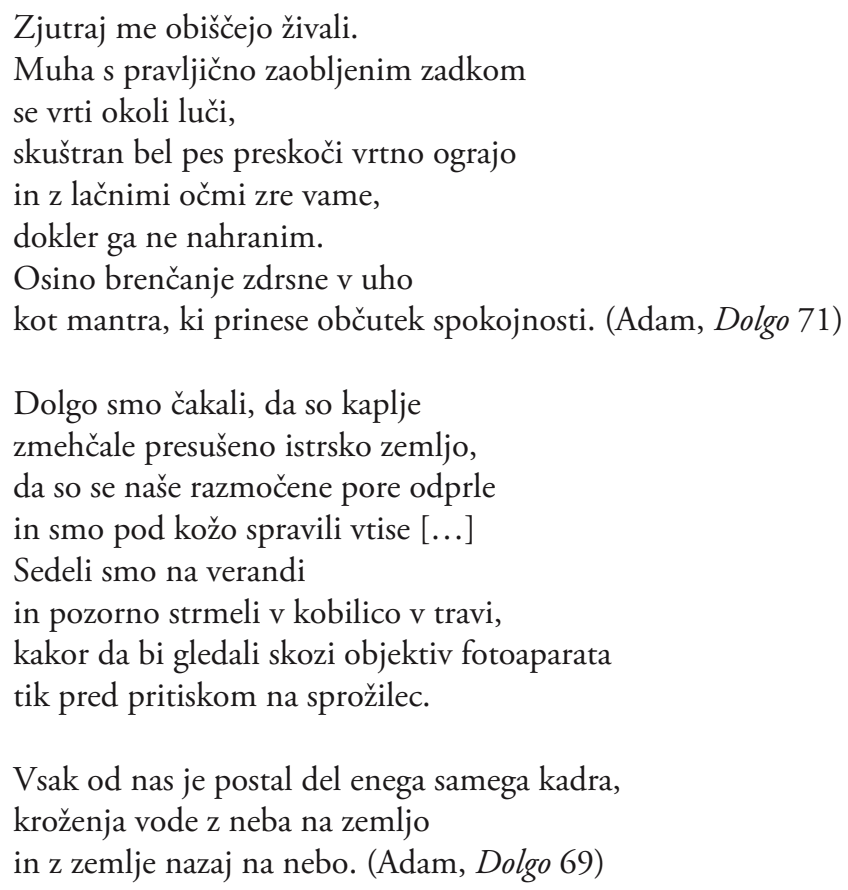

Podoba objektiva $\mathrm{v}$ drugi izmed citiranih pesmi ( $\mathrm{tj}$. naslovni pesmi zbirke), v kateri se tako človeška kot ne-človeška bitja znajdejo hkrati kot opazovalci in opazovani, je skoraj enaka kot tista o Herzogovem dokumentarcu, ki smo jo opazili v pesmi "Raziskovalci se čudijo" Putrle Srdićeve (Putrle Srdić, To noč 23) in tudi pri Alji Adam sproža razgradnjo kartezijanskega dualizma ter vanj ujete zgolj človeške identitete. Živali so kot posrednice pri dekonstrukciji človeške identitete, ki razkrivajo tudi njeno lastno divjost:

Ko bova zbrala pogum

in odrinila zapahe na vratih kot čoln odrine svoj odsev na gladini, ko izpluje se bova naučila hoditi po vseh štirih in [lisicam] sledila v dolino. (Adam, Dolgo 95)

Zapuščanje prividne človeške identitete, kar je seveda prepoznavni ekokritiški motiv, $v$ pesništvu Alje Adam potemtakem pomeni zapuščanje 
strahu, za katerega smo že v začetku pripoznali, da ga pesnica razume kot proizvod kartezijanskega dualizma. Vendar je območje zunaj kartezijanskega dualizma obteženo prav z divjostjo "nenavadnih neznancev«. Motiv očesa tudi Putrle Srdićeva uporabi kot simbol več-kot-človeškega (Putrle Srdić, To noč 24-25), podobno kot smo videli pri Adamovi; oko je uporabljeno kot prispodoba za točko prehoda $\mathrm{v}$ svet zunaj ali bolje rečeno pred kartezijanskim dualizmom, ${ }^{5}$ glede katerega pa prevlada poudarek na njegovi nedostopnosti: "reža otrokovih oči $[\ldots]$ vodi v [...] neprepoznaven [...] prostor, / ki sva se mu že davno iztrgala in o katerem / ne veva nič« (24); »vesolja pod vekami [psice] se nemirno premikajo.» (25)

\section{Sklep}

V pričujočem članku smo poskušali pojasniti razloge za eksplicitno polemiko $s$ kartezijanskim dualizmom, ki se pojavlja kot očitna vzporednica med pesniškima deloma, objavljenima tako rekoč sočasno, z zgolj enim letom razlike, in pri isti založbi. Ob vzporejanju posthumanističnih idej novih materializmov, ki omogočajo razumevanje ne-človeškega in materije kot globoko agentnih, z idejami, ki se izpisujejo iz celote obeh pesniških zbirk, smo ugotavljali, da pripadata pesnici istemu nazorskemu obzorju in da je Descartes skupna točka obeh zato, ker pooseblja antropocentrične temelje evropske metafizične tradicije, ki jih želita v lastnih pesniških konstrukcijah razgraditi. Opraviti imamo $\mathrm{z}$ dvema sorodnima poskusoma ekocentrične rekonceptualizacije človeškega v smislu posthumanističnega več-kot-človeškega, ki pa kažeta različne poudarke. Različna pristopa pesnic ustrezata dvema smerema, ki ju lahko v grobem razločimo znotraj posthumanističnega diskurza: pesniška zbirka Alje Adam ustreza posthumanizmu, ki se osredotoča na zabrisanje ločnice med ljudmi in živalmi, Jana Putrle Srdić pa upesnjuje tudi ali predvsem kiborški posthumanizem, ki se obrača k tehnologiji (Westling 29). ${ }^{6} \mathrm{Z}$ njuno skupno zavezo posthumanističnemu prizadevanju je pojasnjena skupna referenca na Descartesa. V obeh obravnavanih delih se udejanja umetniška artikulacija načel ekološkega neesencialističnega pluralizma in relacionizma ter reprezentacija

${ }^{5}$ Izraz "predkartezijanski« je na mestu ne le zato, ker gre za opis otroka, marveč tudi, ker dikcija jasno izpostavlja, da gre za svet, ki sta se mu opisovana akterja že iztrgala (Putrle Srdić, To noč 24).

${ }^{6}$ Posthumanizem je potrebno ločiti od transhumanizma kot »antropocentrične pripovedi o človeškem preseganju meja lastnega telesa v samokonstrukciji s pomočjo tehnologije« (Clark 63-64). 
ne-človeške delovalnosti telesa/materije. Iz posthumanistično razsrediščenega videnja sveta kot mreže izhaja občutje drugosti oziroma ne-identitete, ki ga lahko razumemo kot glavnega pokazatelja ekološke misli, kot jo začrtajo in razlagajo novi materializmi in Mortonova neidentitetna ekologija: ekološka misel se obrača k več-kot-človeškemu, ki se vselej izmuzne našim poskusom zajeti svet v koncepte in ki ga lahko mislimo le kot konkretnost sveta.

\section{LITERATURA}

Adam, Alja. Dolgo smo čakali na dež. Ljubljana: CSK (Aleph), 2015.

Adam, Alja. Zakaj bi omenjala Ahila. Ljubljana: CSK (Aleph), 2009.

Alaimo, Stacy. Bodily Natures: Science, Environment, and the Material Self. Bloomington, IN: Indiana University Press, 2010.

Allen, Donald. The New American Poetry: 1945-1960. Berkeley, LA; London: University of California Press, 1999.

Barad, Karen. Meeting the Universe Halfway: Quantum Physics and the Entanglement of Matter and Meaning. Durham, NC: Duke University Press, 2007.

Barad, Karen. »Nature's Queer Performativity«. Kvinder, Køn og Forskning / Women, Gender and Research 1.2 (2012): 25-53.

Bauman, Whitney. "The Eco-Ontology of Social/ist Ecofeminist Thought". Environmental Ethics 29.3 (2007): 279-298.

Branch, Michael. "Ecocriticism: The Nature of Nature in Literary Theory and Practice«. Weber Studies 11.1 (1994): 41-55.

Cheney, Jim. »Eco-Feminism and Deep Ecology«. Environmental Ethics 9.2 (1987): $115-145$.

Clark, Timothy. The Cambridge Introduction to Literature and the Environment. Cambridge: Cambridge University Press, 2011.

Claviez, Thomas. "Jamming What Exactly? Some Notes on the 'Anthropological Machine' and Ethics in Derrida, Agamben, Calarco, and Latour". Literature, Ecology, Ethics: Recent Trends in Ecocriticism. Ur. Timo Müller in Michael Sauter. Heidelberg: Universitätsverlag Winter, 2012. 69-80.

Coupe, Laurence, ur. The Green Studies Reader: From Romanticism to Ecocriticism. New York, NY; London: Routledge, 2000.

Curry, Patrick. "Nature Post-Nature«. New Formations. Earthographies. Ecocriticism and Culture 64 (2008): 51-64.

Descartes, René. A Discourse on the Method of Correctly Conducting One's Reason and Seeking Truth in the Sciences. Prev. Ian Maclean. New York, NY; Oxfrod: Oxford University Press, 2006.

Gatens, Moira. Imaginary Bodies: Ethics, Power and Corporeality. New York, NY; London: Routledge, 1996.

Görg, Christoph. "Societal Relationships with Nature: A Dialectical Approach to Environmental Politics". Critical Ecologies. The Frankfurt School and Contemporary Environmental Crises. Ur. Andrew Biro. Toronto: University of Toronto Press, 2011. 43-72.

Gunster, Shane. "Fear and the Unknown: Nature, Culture, and the Limits of Reason«. Critical Ecologies: The Frankfurt School and Contemporary Environmental Crises. Ur. Andrew Biro. Toronto: University of Toronto Press, 2011. 206-228. 
Haraway, Donna. Opice, kiborgi in ženske. Prev. Valerija Vendramin in Tina Potrato. Ljubljana: Študentska založba, 1999.

Hayles, N. Katherine. "Searching for Common Ground". Reinventing Nature? Responses to Postmodern Deconstruction. Ur. Michael E. Soulé in Gary Lease. Washington, DC: Island Press, 1995. 47-63.

Hird, Myra. "Naturally Queer«. Feminist Theory 5.1 (2004): 85-89.

Iovino, Serenella, in Serpil Oppermann. "Material Ecocriticism: Materiality, Agency and Models of Narrativity«.Ecozon@ 3.1 (2012): 75-91.

Keller, David R. »Introduction: What Is Anthropocentrism?«. Environmental Ethics: The Big Questions. Ur. David R. Keller. Malden, MA; Oxford: Wiley-Blackwell, 2010. 59-62.

Legler, Gretchen. »Body Politics in American Nature Writing: 'Who May Contest for What the Body of Nature Will Be?'"Writing the Environment: Ecocriticism and Literature. Ur. Richard Kerridge in Neil Sammells. London; New York, NY: Zed Books Ltd., 1998. 71-87.

Morton, Timothy. Ecology without Nature. Rethinking Environmental Aesthetics. Cambridge, MA: Harvard University Press, 2009 (2007).

Morton, Timothy. The Ecological Thought. Cambridge, MA: Harvard University Press, 2010.

Morton, Timothy. "The Mesh". Environmental Criticism for the Twenty-First Century. Ur. Stephanie LeMenager, Teresa Shewry in Ken Hiltner. New York, NY; London: Routledge, 2011. 19-30.

Morton, Timothy. "Coexistence and Coexistents: Ecology without a World«. Ecocritical Theory: New European Approaches. Ur. Axel Goodbody in Kate Rigby. Charlottesville, VA: University of Virginia Press, 2011. 168-180.

Potocco, Marcello. »Poezija na Prangerju, drugič«. Večer. 15. 6. 2015. Splet. 10. 10. 2021. <https:/www.vecer.com/navaden/201506156122837-6122837>.

Putrle Srdić, Jana. Oko očesu vrana. Ljubljana: CSK (Aleph), 2020.

Putrle Srdić, Jana. To noč bodo hrošč prilezli iz zemlje. Ljubljana: CSK (Aleph), 2014.

Rigby, Kate. "Gernot Böhme's Ecological Aesthetics of Atmosphere«. Ecocritical Theory: New European Approaches. Ur. Axel Goodbody in Kate Rigby. Charlottesville, VA: University of Virginia Press, 2011. 139-152.

Sagan, Dorian, in Lynn Margulis. Acquiring Genomes: A Theory of the Origin of Species. New York, NY: Basic Books, 2002.

Snyder, Gary. The Gary Snyder Reader: Prose, Poetry, and Translations. Washington, DC: Counterpoint, 1999.

Sullivan, Shannon. Living Across and Through Skins: Transactional Bodies, Pragmatism, and Feminism. Bloomington, IN: Indiana University Press, 2001.

Warren, Karen J. »The Power and the Promise of Ecological Feminism«. Environmental Ethics: The Big Questions. Ur. David R. Keller. Malden, MA; Oxford: WileyBlackwell, 2010. 281-291.

Westling, Louise. "Literature, the Environment, and the Question of the Posthuman«. Nature in Literary and Cultural Studies: Transatlantic Conversations on Ecocriticism. Ur. Catrin Gersdorf in Sylvia Mayer. Amsterdam, New York, NY: Rodopi, 2006. 25-47.

Wheeler, Wendy. The Whole Creature: Complexity, Biosemiotics and the Evolution of Culture. London: Lawrence and Wishart, 2006.

Wolfe, Cary. "Human, All Too Human: 'Animal Studies' and the Humanities». PMLA 124.2 (2009): 564-575. 


\section{The Posthumanist Critique of Cartesian Dualism in the Lyric Poetry of Alja Adam and Jana Putrle Srdić}

Keywords: contemporary Slovenian poetry / Adam, Alja / Putrle Srdić, Jana / critique of Cartesian dualism / ecofeminism / posthumanism / ecocriticism

This article examines the explicit critique of Cartesian dualism as the epitome of Western anthropocentrism as expressed in two contemporary Slovenian poetry books, Dolgo smo čakali na dež (2015) by Alja Adam (1976) and To noč bodo hrošč prilezli iz zemlje (2014) by Jana Putrle Srdić (1975). Adam and Putrle Srdićs poetry thematizes the body, and the relationship between the human and the animal in the light of the posthumanist more-than-human identity, which is associated with non-identity, i.e. that which defies any human concept. Both poets refuse the hierarchical and any significant distinction between humans and animals, but their approaches correspond to two directions that can be distinguished within the posthumanist discourse: while Adam's work can be categorized as the type of posthumanism that focuses on blurring the boundary between humans and non-human animals, that of Jana Putrle Srdić can be primarily classified as cyborgical posthumanism, which undermines the Enlightenment concept of man by intertwining humans and machines. While Adam's ecofeminist ideas lead her to exemplify in her writing the practice of conscious embodied existence, which also explains the panerotic tendencies of her poetry, Putrle Srdićs poetry, with references to posthumanist ideas of Gary Snyder and Donna Haraway, systematically deconstructs the binarism of nature and culture, and also that of body and mind, on the basis of the idea of material (i.e. technological or biological) mediation of all (human and non-human) perception.

1.01 Izvirni znanstveni članek / Original scientific article UDK 821.163.6.09-1"20"

DOI: https://doi.org/10.3986/pkn.v44.i3.05 